\title{
BAUDELAIRE MAU VIDRACEIRO
}

Viviana Bosi

- (BAUDELAIRE, Charles. O Spleen de Paris: pequenos poemas em prosa. Trad. Leda Tenório da Motta. Rio de Janeiro: Ed. Imago, 1995: 34-35)
Podemos começar pela leitura do trecho final do poema em prosa, "O mau vidraceiro", de Baudelaire:

A primeira pessoa que vi na rua foi um vidraceiro, cujo pregão cortante, dissonante, me chegou através da pesada e suja atmosfera parisiense. É-me, aliás, impossível dizer por que fui tomado, em relação a esse pobre homem, de ódio tão repentino e despótico.

"Ei! Ei!", gritei-lhe que subisse. Entretanto refletia, não sem algum contentamento, que, ficando o quarto no sexto andar e sendo a escada bastante estreita, seria difícil para o homem operar sua ascensão sem enganchar por toda parte os ângulos de sua frágil mercadoria. Finalmente apareceu-me: examinei curiosamente todos os vidros e lhe disse: "Mas como? Não tem vidros de cor? Vidros cor de rosa, vermelhos, azuis, vidros mágicos, vidros do paraíso? Como é descarado! Ousa passear pelos bairros pobres sem ao menos trazer vidros que tornem a vida bela!" E o empurrei vivamente para a esca$\mathrm{da}$, onde tropeçou resmungando.

Cheguei até o balcão, apanhei um vasinho de flores e, quando o homem reapareceu na soleira da porta, deixei cair perpendicularmente meu engenho de guerra sobre a parte de trás de seu fardo; o choque o derrubou e ele acabou de quebrar sobre as costas toda a sua pobre fortuna ambulatória, que fez o barulho estrondoso de um palácio de cristal arrebentado por um raio.

E inebriado com minha loucura, gritei-lhe furiosamente: "que tornem a vida bela! a vida bela!"

Essas brincadeiras nervosas não deixam de comportar algum perigo, podemos pagar caro por elas. Mas que importa a eternidade da danação para quem encontrou num segundo o infinito do gozo?*

É sempre com renovado prazer que apresento este poema em prosa para os alunos do primeiro ano de Letras, e vejo como o texto lhes provoca, geralmente, uma imediata antipatia pelo poeta. Como é possível que um autor que aprendemos a admirar cegamente, e que se tornou o clássico da modernidade, seja tão desconsiderado com o pobre trabalhador, tão hedonista, a ponto de pouco se importar com o outro e, ao contrário, consciente e cruelmente, destratá-lo e mesmo causar-lhe prejuízo? E justificar tal ação pelo prazer estético imediato, pouco se importando com as conseqüências? 
Uma parte da crítica mais tradicional considera-o um exemplo a mais da tendência histérica de Baudelaire, que cultiva o "espírito de mistificação" e o satanismo do dândi decadentista e aristocrático. Agir movido pelo impulso perverso do "humor negro" - como o leu também André Breton, que incluiu "O mau vidraceiro" em sua antologia ${ }^{1}$ - teria como acicate o desejo de superar a própria infelicidade, vencendo as circunstâncias da vida, o que levaria a essa exteriorização da louca satisfação de um segundo, mesmo às custas da desgraça própria e alheia. Resumindo idéias de Freud, Breton apresenta o humor como uma defesa contra o sofrimento, pela inteligência rápida do eu, que reverte as expectativas enxergando o oposto da infelicidade, e assim protege-se de sucumbir à dor. Haveria, então, um efeito liberador nesta recusa em ser derrotado pelas circunstâncias infelizes, promovendo-se uma "revolta superior do espírito".

O mal-estar causado pelo texto pode ser experimentado em muitos outros poemas e ensaios de Baudelaire. Pois quem quiser ler sua obra de modo fundamentalista, julgando-a a partir da letra, pode dali extrair conclusões incoerentes, dada a sua provocativa ambigüidade. ${ }^{2}$ Se, de fato, ele é "o maior exemplo de modernidade em qualquer língua" (no dizer de Eliot, e de vários outros), precisamos apreender o movimento em realidade contraditório da própria modernidade e, como bem exprimiu Oehler, vislumbrar em sua neurose pessoal, a encarnação das neuroses da cultura de uma época. ${ }^{3}$

É surpreendente, à primeira vista, que o poeta pregue tão firmemente a autonomia do belo em relação ao bom e ao verdadeiro, chegando a parafrasear trechos de Poe para tecer os maiores louvores à poética parnasiana de Gautier e, a seguir, em comentário de igual veemência, eleve com entusiasmo as cançôes trabalhistas de Dupont, considerando como suas principais qualidades o aspecto utópico e a fé na justiça social que delas emana.

\footnotetext{
${ }^{1}$ Ver o prefácio, intitulado "Paratonnerre" (BRETON, A. Anthologie de l' humour noir. Paris: Jean-Jacques Pauvert, 1966, edição revista).

${ }^{2}$ Os exemplos que se seguem nesta e na próxima página foram reproduzidos de trechos publicados no meu texto "Contradição e unidade em Baudelaire", Literatura e Sociedade n.6. São Paulo: DTLLC/USP, 2001-2002.

3 ..."depois de 1848, os melhores representantes da 'art-névrose', Baudelaire e Flaubert, reconheceram as tendências e tentaçôes de suas neuroses individuais como correspondências do procedimento político de sua própria geração e classe, pondo a descoberto a 'neurose objetiva' de sua época"... "eles a analisaram, graças justamente ao íntimo conhecimento da própria psique, com uma agudez e plenitude insuperáveis em toda a literatura desde então.” Em: OEHLER, D. “Art Névrose. Análise sócio psicológica do fracasso da revolução em Flaubert e Baudelaire". Novos Estudos Cebrap, 32, março de 1992: 110.
} 
Não muito longe, em outro ensaio crítico, Baudelaire vitupera contra a "escola da vingança": esses literatos que, ao pretender divulgar as idéias de Proudhon (que ele admirava), colocam no papel "carícias servis às paixões dos escravos em cólera".

Em várias passagens, atacará tanto a "escola burguesa" quanto a "escola socialista", visto que ambas tratam a arte como propaganda, pretendendo "moralizá-la". O que o indigna, em especial, é a falsidade dos romances ditos "honestos", açucarados pela hipocrisia filistina, seja ela conservadora (de sentimentalismo do tipo "notário") ou soi-disant revolucionária (de "sentimentalismo materialista").

Após declarar que sua religião e glória residem nas imagens, afirma, em outro contexto, que "o gosto imoderado da forma" produz aberraçooes morais, e conduz ao orgulho e ao egoísmo pois, a "paixão feroz do belo" pode apagar a "noção do justo e do bem", como um câncer que devora os valores éticos e desemboca no nada. Em vários trechos Baudelaire defende ardorosamente a utilidade da arte. Assevera que a imaginação nunca poderia ser perniciosa, e não há incompatibilidade real entre ciência, justiça e beleza.

Satiriza os homens alheios ao próprio tempo, que preferem acreditar nos deuses gregos ou estudar os rituais egípcios a tomar partido nas revoltas populares prementes. Irrita-se com os eruditos cuja cultura é um pastiche dos clássicos: "deplorável mania que tende a fazer do homem um ser inerte e do escrivão um comedor de ópio."

Porém, vota o mesmo desprezo aos "profetas do futuro" que submetem a literatura a um alvo moral, diminuindo-a ao tentar "adaptar-se... aos problemas sociais, tais como os trazidos pela revolução de $1830 "$.

Renega tanto a poesia "marcada pelo miserável caráter da circunstância e da moda" quanto as artificiais "tolices clássicas" de alguns de seus contemporâneos, que não enxergam a vivacidade do atual. Em outros momentos, sente saudades da antiguidade, aurora do mundo.

Recusa a negligência espontânea do transbordamento romântico assim como o realismo vulgar em sua "descrição minuciosa do acessório" e suas "aventuras triviais"; e ainda, o neoclassicismo afetado que evita as liçōes da rua, preferindo imitar os modelos acadêmicos.

Admira, porém, Victor Hugo, Balzac e Gautier: para ele, três grandes espíritos, em que forma e sentimento ajustam-se perfeita- 
mente, sem prejuízo da imensa diferença de seus temperamentos e correspondentes estilos. Em Delacroix e em Flaubert encontra a qualidade essencial da imaginação, que penetra o real e o transfigura. ${ }^{4}$

Uma leitura superficial julgá-lo-ia caprichoso e mutável em seus princípios, quer éticos, quer estéticos, ou, pior ainda, poderse-ia recortar de sua obra boutades isoladas, convenientes para concluir que Baudelaire era misógino, desagradavelmente reacionário e frívolo, ou ainda, um revoltado radical, mas inconseqüente. Essa aparente oscilação, ou gosto do paradoxo, presta-se a equívocos de leitura, e aplica-se também a outros traços fundamentais de sua obra. ${ }^{5}$ Mas, acreditamos que há nela "profonde unité", malgrado suas aparentes "confuses paroles".

De toda forma, não há dúvida quanto ao seu ódio intenso contra o hipócrita juste-milieu, que se pretende democrático, preterindo toda verdadeira beleza e justiça em nome da imediaticidade de soluções pragmáticas. Dolf Oehler bem percebeu esse traço em todos os ataques de Baudelaire, seja contra a multidão, seja contra o burguês: o horror aos chavôes engajados dos "macacos do sentimento", cuja boa-consciência alia-se a um senso filantrópico trivializante.

\footnotetext{
${ }^{4}$ As citaçôes acima advêm dos seguintes ensaios de Baudelaire: "Théophile Gautier" (I), "Pierre Dupont"(I), "Les drames et les romans honnêtes", "L'école païenne", "Victor Hugo" ("Réflexions sur quelques-uns de mes contemporains"), "Le peintre de la vie moderne", "L'oeuvre et la vie d'Eugène Delacroix", "Conseils aux jeunes littérateurs". Em Oeuvres Complètes. Bibliothèque de la Pléiade. Org. Claude Pichois. Paris: Gallimard, 1976: II.

${ }^{5}$ São muitos os estudiosos de Baudelaire que citam estes ou outros exemplos como prova das tensões irreconciliáveis de sua poesia que seriam, no entanto, necessárias para a expressão das contradições da própria modernidade. Dentre eles destaco o livro de M. HAMBURGER - La verdad de la poesia (tensiones en la poesía moderna de Baudelaire a los años sesenta). México: Fondo de Cultura Económica, 1991 - cujo primeiro capítulo exibe coincidências com os exemplos apresentados do começo deste estudo, que atestam a semelhança inicial da análise. Também M. BERMAN em Tudo que é sólido desmancha no ar (São Paulo: Cia. das Letras, 1987) reflete sobre a impossibilidade de tomar partido contra ou a favor da modernidade, à medida que esta aposta com júbilo nas possibilidades do futuro ao mesmo tempo que teme o automatismo, a dissolução dos valores, etc. Igualmente H. FRIEDRICH em Estrutura da lírica moderna (São Paulo: Duas Cidades, 1978) e M. CALINESCU, em Five faces of modernity (Durham: Duke U.P., 1987) opõem a repulsa ao progresso unicamente material destinado à rápida obsolescência à atração pela novidade do tempo presente, e acrescentam, no plano da arte, a recusa da imitação do passado versus a permanência de um ideal transcendente de beleza.
}

(OEHLER, Dolf. Quadros parisienses. Estética antiburguesa 1830-1848. São Paulo: Cia. das Letras, 1997.) 
O histórico minucioso do crítico alemão permite situar com riqueza muito maior o processo de aguçamento das contradições entre o lugar do "burguês", do "operário" e do outsider social que é o boêmio. A mais forte repulsa de Baudelaire concentra-se na figura emblemática de George Sand, o símbolo da mulher intelectual bem intencionada que idealiza os pobres, simplificando as contradiçôes do humano. ${ }^{6}$ Entretanto, devemos lembrar o quão sincera era a admiração do poeta por Victor Hugo, pois nele vê a "palpitação da vida”, a grandeza do concreto. Verifica que seus ideais de fraternidade encontram-se tão entranhados na obra que se fizeram quase invisíveis - dada a sua onipresença - e ali nada se impóe mais alto que a beleza incondicional.

Embora a conversão do cotidiano em "luxe, calme et volupté" seja, de súbito, cortada pela exposição obscena da carniça, numa clara paródia às tentativas incorpóreas de transcendência de certo romantismo, ao mesmo tempo Baudelaire distancia-se com igual desdém do "realismo pedreiro". Todos sabem que ele foi condenado pelo mesmo tribunal de Flaubert e que recusava a acusação de "realismo", pois nunca almejou a simplesmente copiar a realidade "em estado de dicionário", mas transformá-la de acordo com a tonalidade de um surnaturalisme.

Conclui-se, portanto, que suas diatribes não o colocam contra o melhor realismo ou o alto romantismo, e sim, opõe-no a certos diluidores, incapazes de alçar-se à capacidade criativa e superar a reprodução das impressões imediatas.

\section{O poema em prosa}

Forma nascida no romantismo, o poema em prosa dirige sua força de rebeliāo contra as classificações de gênero. Aglutina a especulação e o lirismo, concedendo-se liberdade para a digressão do pensamento, e superando as regras dos versificadores tradicionais, que julgavam a poesia a partir das harmonias sonoras metrificadas segundo os tratados clássicos.

A própria concepção do poema em prosa, reflete Susanne

- (BERNARD, Suzanne. Le poème en prose. De Baudelaire jusqu' à nos jours. Paris: Librairie Nizet, 1959.) Bernard," traduz a ambição de quebrar a unidade clássica de tom. As contradiçôes do indivíduo moderno só poderiam se exprimir num gênero sinuoso e partido como a serpente, compreende o po-

\footnotetext{
${ }^{6}$ Não podemos avaliar se esta crítica é de fato justa, porque não conhecemos o suficiente os escritos da autora - infelizmente, só vimos o filme sobre a vida de Chopin, "À noite sonhamos", em que ela aparece sob uma luz não muito positiva...
} 
eta. Ao escapar do verso organizado, composto de compassos reiterados, o choque e a desagregação têm voz, possibilitando a expressão da pluralidade dos ritmos e conflitos desse homem urbano insatisfeito. ${ }^{7}$

No poema em prosa, o autor d'O spleen de Paris manifestou seus paradoxos entre vida e obra muito claramente. Neste gênero novo, ele pôde novamente desafiar-se e vencer como poeta, uma vez que talvez fracassasse como autor da vida. Compreende Berardinelli que, "por trás do voluntarismo teórico da poética de Baudelaire, há uma espécie da paralisia letárgica da vontade" pois "o seu gesto estilístico, tão peremptório, ergue-se sobre o caos de uma existência incapaz de encontrar uma ordem"* $\mathrm{O}$ "pêndulo obsessivo entre uma ordem sonhada e as invasões angustiantes do cotidiano"* encontram expressão e trégua no poema em prosa, no qual o ideal pode ser rodeado pelos seus limites e protegido pela reflexão. Por exemplo, no "Quarto duplo", em que o sujeito lírico despreza a realidade que o fere e que acontece além de sua determinação, criando outra no lugar (ou assim o desejando) pela fantasia.

O mais interessante no ensaio de Berardinelli é sua percepção, da qual partilhamos, de que, para Baudelaire, há uma intenção ética na busca estética, de desmascarar o falso belo como um falso bem. Este falso bem está associado, em geral, à ideologia burguesa, anti-heróica e esclarecida, e a uma concepção de modernidade relacionada ao trabalho mecânico e ao progresso. Ao contrário, tudo o que é escandaloso, bizarro, de aparente mau gosto, o atrai, justamente por causar aversão neste mundo mediocremente administrado. A forma híbrida do poema em prosa convém, assim, pelo seu inerente inconformismo, voltando-se, ao mesmo tempo, a favor e contra a modernidade.

Os textos de Houssaye e Baudelaire

Situemos o contexto literário d'“O mau vidraceiro". Baudelaire parece parodiar um texto do poeta Arsène Houssaye, editor de La Presse (onde foi publicado, junto a outros poemas em prosa em 26 de agosto de 1862). Leiamos excertos d'“A canção do vidraceiro", do referido amigo (provavelmente composto em 1849, e publicado em 1857), com o qual meus alunos, a princípio, se identificam muito mais.

\footnotetext{
${ }^{7}$ A esse respeito, ler a "Dedicatória" ao Spleen de Paris, em que Baudelaire explicita a relação entre essa nova forma de texto e a vida moderna.
}

* (BERARDINELLI, A. "Baudelaire em prosa". Da poesia à prosa. São Paulo: CosacNaify, 2007: 43.) *(: 44) 
• (HOUSSAYE, Arsène. "La chanson du vitrier". Em BAUDELAIRE, C. "Notices, notes et variantes". Oeuvres Complètes. Op. cit.: 1309-1311.)

- (BAUDELAIRE, C. O spleen de Paris: pequenos poemas em prosa. Tradução de António Pinheiro Guimarães Lisboa: Relógio d'água, 1991: 28.)
Ao ouvir o repetido pregão de um pobre vidraceiro na rua, e encontrá-lo quase a morrer de fome, o sujeito lírico, tomado de piedade, convida-o a entrar numa taberna consigo:

Eu brindei com ele. Mas seus dentes batiam contra o copo, e ele desmaiou; sim senhora, ele desmaiou; - o que lhe causou um prejuízo de três francos e dez soldos, a metade de seu capital! pois eu não pude impedir seus vidros de quebrarem. $\mathrm{O}$ pobre homem voltou a si dizendo ainda:

Oh! vidraceiro!

Ele nos contou como partira de manhã da rua dos Ingleses, - uma rua em que não há sequer quatro fogos no inverno, - como ele lá deixara mulher e sete filhos que já haviam dado um ano de miséria à República, sem contar todos aqueles dados à realeza. Desde a manhã, ele havia gritado mais de mil vezes:

Oh! vidraceiro!

$[\ldots]$

Eu estava silencioso diante desta suprema miséria; não ousava oferecer mais nada a este pobre homem, quando o taberneiro lhe disse: "Por que você não procura alguma obra de caridade? - Ora essa! Interrompeu-o bruscamente o vidraceiro, será que sou mais pobre que os outros? Toda a gentalha da praça Maubert está na mesma situação. Se nós quiséssemos viver à farta, como se diz, comeríamos o resto de Paris em quatro refeições.

Oh! vidraceiro!

Ele retornou a sua mulher e a seus filhos, um pouco menos triste que de manhã - não porque ele tivesse encontrado a caridade, mas porque a fraternidade havia brindado com ele. $\mathrm{E}$ eu, eu voltei com esta música dolorosa que me dilacera o coração:

Oh! vidraceiro!*

Ao repisar lugares comuns, a banalidade de Houssaye confunde boas intenções com arte, escrevendo um texto cujo intuito didático é evidente. Apresentando a miséria da família do vidraceiro, que se assemelha a outras centenas de desgraçados, retrata em palavras o que todos nós sabemos e, ao invés de propor qualquer solução, apenas se lamenta. Não nos oferece nada além da descrição do problema, fazendo o que Baudelaire condena: "atreve-se a passear pelos bairros pobres e nem sequer tem vidros que façam ver a vida com beleza". * Há nele conformismo e aceitação resignada dos males da pobreza, de forma que o principal objetivo do texto vi- 
sa a ser, quem sabe, inclinar a nossa consciência a um vago espírito de fraternidade que não oblitera o sentimento de superioridade do ilustrado passante, o qual, num momento de errática boa vontade, decide-se a ouvir o grito reiterado do pobre.

Imagine-se, pois, o mal-estar causado por "O mau vidraceiro”, publicado sob os auspícios do mesmo Houssaye, a quem Baudelaire, como se sabe, ofertou o conjunto dos pequenos poemas em prosa. Ao ler o texto escrito pelo nosso provocador, alguns anos depois, os vidros quebrados pela caridade adquirem toda a conotação lamentável do humor negro.

Na famosa "Dedicatória", que foi editada em forma de carta, na revista, no mesmo dia em que o poeta publicou o conjunto de textos em que se insere "O mau vidraceiro", ele refere-se ao seu patrono nos seguintes termos: "Você mesmo, caro amigo, não tentou traduzir numa canção o grito estridente do Vidraceiro, e exprimir numa prosa lírica todas as desoladoras sugestôes que esse grito leva às águas-furtadas, através das mais altas brumas da rua?" ${ }^{*}$

Baudelaire revela, além do sintoma da doença, a causa da degradação das relações entre os homens, em que se deformou a possibilidade de libertação desvendando a hipocrisia amortecedora da "caridade". Não quer se comprometer com o mecanismo de má infinitude reforçando o mesmo sistema que escraviza o vidraceiro, os pobres seus vizinhos e ele mesmo. O mesmo "prazer aristocrático de desagradar" que guia seus histéricos procedimentos contra o "mau vidraceiro", representante do realismo rasteiro e repetidor ad infinitum da lógica do útil sem beleza, fá-lo aborrecer com igual intensidade o seu aparente contrário: o romantismo açucarado do burguês filisteu, que em tudo enxerga o "ange” celestial (Houssaye compara o vidraceiro a Jesus Cristo e Paganini). Ao tentar sacudir a consciência do leitor, quer, através de uma atitude desafiadora, promover uma subversão semelhante às vanguardas do século vindouro, pleiteando "La vie en beau?".

Oehler, em sua análise de alguns poemas em prosa de Baudelaire, observa que mesmo a explicação inicial do texto "O mau

\footnotetext{
${ }^{8}$ Por sinal, comenta Jean Ziegler nas notas a "Le mauvais vitrier" para a edição da Pléidade: "E não está excluído que, ao se colocar sob a patronagem deste [Houssaye], aquele [Baudelaire] não tivesse tido também alguma intenção irônica, perceptível no emprego do verbo tentar e no sentido ambíguo do adjetivo desoladoras." (BAUDELAIRE, C. Oeuvres Complètes. Op. cit.: I,1311).
}

- (BAUDELAiRe, C. O Spleen de Paris: pequenos poemas em prosa. Trad. Leda Tenório da Motta. Op. cit.: 16, com pequena mudança na tradução.)

"(OEHLER, D. O velho mundo desce aos infernos: auto-análise da modernidade após o trauma de 1848 em Paris. São Paulo: Companhia das Letras, 1999.) 
$(: 298$.

(: 299.)

(POE, E. A. Tales of mystery and imagination. Everyman's Library. Londres e Nova York: J. M. Dent \& Sons Ltd e E.P. Dutton \& Co. Inc., 1946, reimpressão.)

(BAUDELAIRE, C. O Spleen de Paris: pequenos poemas em prosa. Trad. Leda Tenório da Motta. Op. cit.: 32) vidraceiro" sobre a patologia que leva à inação ou às ações inconseqüentes, não é fruto de um pensamento meramente cínico e blasé. Ele a vê como fina ironia do poeta, que "insurge-se contra a exigência de uma reprodução infinita da prosa tristonha da condition ouvrière, que num certo sentido é também a sua." E conclui: "A anedota do castigo do vidraceiro ganha vida, sobretudo, a partir da tensão entre o empirismo do cotidiano... e a agressividade sublime do devaneio poético."*, mesmo sabendo que "celebra a felicidade infinita da revolta como compensação, não apenas de uma vida na miséria, mas da 'eternidade da danação". *

Não há dúvida que a influência da leitura de Poe, especialmente do conto "The imp of the perverse" ("O demônio da perversidade"), " preside este poema em prosa: a tentação do abismo, "o gosto inato da dissolução" (nas palavras de José Paulo Paes), a zombaria quanto ao verdadeiro sentido das ações humanas, o transbordamento irreprimível do impulso para a vingança e para a transgressão - e a desconfiança rebelde quanto à rasa ciência dos iluministas de boa vontade, que julgam tudo compreender à luz da razão, são os motivos que irrompem nos fluxos do texto, e que vão se encorpando até desembocar no desafogo final, contrapondo-se à domesticação ou subserviência do homem às injunções da sobrevivência. Além da influência sobre o tema de Baudelaire, nota-se que este aproveitou o próprio ritmo de construção do conto de Poe que, como ele, começa pelas elucubraçōes filosóficas e psicológicas sobre a origem do comportamento humano de forma devaneante e, então, seguem-se exemplos de ações que antecipam o que irá acontecer, como que a instilar a idéia de que mesmo os homens mais inaptos para as grandes realizações "encontram num minuto uma coragem de luxo para executar atos os mais absurdos e muitas vezes até mesmo perigosos.”* . Mas o tom é ainda lento, em ociosa divagação, como ondas largas. $\mathrm{O}$ andamento de "O mau vidraceiro" varia: no começo, a nonchalance desinteressada, como alguém que, estóico, admite elegantemente a inutilidade de qualquer ação e permanece indiferente. Então, de golpe, a narrativa de uma cena se desenrola, como se o desenlace apressasse o final, criando um efeito acelerado de surpresa. O narrador chega até a fúria despropositada com a qual reage de súbito contra mais uma gota d'água na sua impotência. E o texto termina abruptamente com uma revelação - no caso de Baudelaire, fragorosamente, com a explosão do palácio de cristal como um raio - figurando a iluminação brusca que teve o personagem. 
Se ambos os textos, o de Poe e o de Baudelaire, tentam desmistificar a ingenuidade das luzes, cujos defensores supõem que a ciência irá retificar o comportamento humano, conduzindo ao progressivo esclarecimento, n' "O mau vidraceiro" a compulsão por agir de forma inexplicavelmente anti-social termina desmascarando a pretensão desta ordem indigente. Verdade que tanto um quanto outro protagonista sabem que irão pagar caro pelo momento intempestivo, que levará o primeiro à prisão e o outro, talvez, à condenação eterna, mas ao mesmo tempo, o alívio libertador parece compensar todo prejuízo. A cena inopinada do final justifica as divagaçôes do começo, ilustrando as dificuldades e recusas de agir de acordo com um molde programado buscando um fim prático imediato. Articula-se, no texto, a negação do tempo presente e a aspiração a inaugurar um tempo utópico, como um incêndio repentino.

Suspeitamos que muito do spleen (tédio melancólico) provém justamente da impossibilidade do idéal, num momento de estagnação que se seguiu às grandes esperanças de transformação detonadas pelo processo revolucionário da virada do século. Um jovem chega à vida adulta embebido de ideais de transformação, para não encontrar vazão na realidade. Por isso tantas vezes ele apregoa a ação que se assemelhe ao sonho como a única que o pode apaixonar.

\section{Contra e a favor da modernidade}

No ensaio em homenagem a Delacroix, o autor d'As Flores do $M a l$ se refere à natureza como um grande magazine ou dicionário, que é necessário imantar com o sol interior do poeta, para compor pela imaginação transformadora, ${ }^{*}$ criando "uma magia sugestiva que contenha ao mesmo tempo o objeto e o sujeito, o mundo exterior ao artista e o próprio artista”. ${ }^{\circ} \mathrm{O}$ escritor que julga descrever o real fidedignamente, prescindindo da "magia evocatória" para penetrar o mundo, revela-se insuficiente para o poeta, cujas imagens do infinito sublime são tão ou mais elevadas do que as do apogeu do romantismo a ele anterior:

Aquele que chama a si mesmo realista, palavra ambígua e cujo sentido não é bem determinado, e que denominaremos, para melhor caracterizar seu erro um positivista, diz: 'Quero representar as coisas tais como elas são, ou tais como seriam, supondo que eu não exista'. O universo sem o homem. E aquele, o imaginativo, diz: 'Quero iluminar as coisas com meu espírito e projetar seu reflexo sobre os outros espíritos."
"(BAudelaire, Charles. "A obra e a vida de Eugène Delacroix". Escritos sobre arte. Org. e trad. Plínio Augusto Coelho. São Paulo: Edusp e Imaginário, 1991.)

" ("A arte filosófica". Idem: 71.)

"("A obra e a vida de Eugène Delacroix". Op. cit.: 95). 
- (Cf. PLATÃO. "Livro X da República" e "Fedro". Em Diálogos. Belém: Univ. Fed. do Pará, 1975.)

-(SARTRE, J.-P. L'imaginaire Paris: Gallimard, 1940.)
Baudelaire tem plena consciência da ingenuidade tola do artista que crê poder apreender o real, pressupondo que a linguagem possa interpor-se entre ele e o mundo como um vidro transparente. Ao expor a fachada falseada pela ideologia, carreia para a obra o aspecto ilusório que a aparência impóe. Assim, penetrando criticamente em ambas as visões do mundo, romântica e realista, Baudelaire as estiliza para seus próprios fins: "o horror da vida e o êxtase da vida."

Para Platão, como sabemos, a mimese comporta um caráter ao mesmo tempo estético e moral: as imagens tanto podem influenciar o cidadão a tornar-se amante do bem e da beleza, quanto vicioso e dominado pelas emoções mais baixas, a depender da perspectiva do artista. Por isso, controlar a representação é fundamental para a organização justa da cidade. * A questão reaparece de maneira modificada em Baudelaire, pois não será a cópia aparentemente fiel a melhor, uma vez que vivemos no mundo alienado da mercadoria, e sim aquela que remete ao ideal, só acessível através da magia sugestiva do artista. Também desse ponto de vista é falho o texto de Houssaye, porque prescinde da necessária embriaguez (ou loucura inspirada, lembrando o "Fedro") que supera a expressão cutânea do real. Houssaye empobrece a noção de mimese supondo-a retrato comprometido com o sensório e o sentimental, e não potência deslocadora, transformadora, tropos e metáfora, portanto forma de aprendizado superior. ' Em "Fedro", Sócrates já antecipa a teoria aristotélica da mimese como conhecimento, portanto, abertura ao outro e ao mundo, com a singularidade de equiparar a inspiração poética ao amor. Assim, diferencia os amantes (e, por extensão, os poetas e sofistas) em categorias: são condenáveis os que se inclinam a uma prática de Eros apenas sensorial, e apreciáveis quando o amor os inflama à ascensão, ao ideal que provém da divindade.

Duas formas de mimese se confrontam nos textos de Houssaye e Baudelaire: a que se submete ao real, julgando que o tempo presente, tal como ele nos é mostrado empiricamente, seria a única verdade, e a que procura, pela imaginação, um devir, um horizonte virtual. Pois a imagem envolve um certo nada, afirma Sartre: vaivém entre a projeção e a descoberta, intui relaçōes novas entre objetos anteriormente estranhos entre si. Por isso, o filósofo consi-

\footnotetext{
9 ..."e, por assim dizer, de uma maneira aristotélica, [...] é indestrutível a antinomia entre o espírito poético puro e o espírito didático." (BAUDELAIRE, C. "A arte filosófica”. Op. cit.: 73)
} 
dera a imagem "correlativo transcendente" do desejo do homem: um constructo se formando dinamicamente, entre o que existe e o que pode ser criado.

Qual seria então o ideal de beleza a que o eu-lírico aspira? Onde está? Procuremo-lo no "Quarto duplo", ${ }^{10}$ onde a atmosfera de devaneio "tem ligeiros tons de cor-de-rosa e de azul", como os vidros sonhados pelo poeta. Saudade e desejo impregnam o ambiente, espiritualizado pelo odor da ausência e aliviado do peso acabrunhante do presente. O que, acima de tudo, provoca a beatitude, o sentimento de paz e harmonia? É a impressão de que "Já não existem minutos, já não existem segundos! O tempo desapareceu; é a Eternidade que reina, uma eternidade de delícias!"

Quando mergulhado nessa fantasia, eis que batem à sua porta cobradores de vários tipos, que vêm lhe devolver a vida cotidiana: "Oh! Sim! O Tempo reapareceu; o Tempo reina agora soberano" - e logo adiante: "Garanto-vos que os segundos, agora, são fortemente e solenemente acentuados", como que a submeter o homem à sua implacável dominação.

O mar e o céu (como também a multidão na cidade) - toda a imagem do infinito - parecem causar a Baudelaire, ao lado de um deleite enorme, pela sua variabilidade e amplitude, o terror do contraste, ao perceber-se submetido a um tempo limitado, contra o qual é necessário lutar, pela arte tão-somente. Como uma forma de superação, a poesia pode auxiliar a suportar "o tremendo fardo do Tempo que te despedaça os ombros e te verga para a terra", aquele mesmo fardo que o vidraceiro carrega aos ombros, e a quem ele daria esse conselho, complementar ao brado "A vida bela!": "É hora de embriagar-se! Para não serem os escravos martirizados do Tempo, embriaguem-se; embriaguem-se sem descanso! Com vinho, poesia ou virtude, a escolher."

Dois autores de formação teórica diversa concluem de modo semelhante haver na obra de Baudelaire um anseio intenso de fugir do tempo e do espaço prosaicos, transfigurando-os pela poesia.

$\mathrm{Na}$ visão de Bachelard, próxima à fenomenologia, "o poeta destrói a continuidade simples do tempo encadeado", procurando estabelecer um tempo vertical, que jorra, diferente do comum,

10 "La chambre double" pode ser traduzido igualmente por "O quarto de casal", conforme prefere Leda Tenório da Motta. Mas, para os fins desta leitura, a outra opção de título explica melhor o nosso comentário. Para os trechos citados deste poema em prosa, seguimos a edição portuguesa de $O$ spleen de Paris, traduzido por António Pinheiro Guimarães. Op. cit.: 17-19.
"(BAUDELAIRE, C. "Embriaguem-se" O Spleen de Paris: pequenos poemas em prosa. Trad. Leda Tenório da Motta. Op. cit.: 112)

" (BACHELARD, Gaston. "Instante poético e instante metafísico". O direito de sonhar. São Paulo: Difel, 1985: 183.) 
(BAUDELAIRE, C. O Spleen de Paris: pequenos poemas em prosa. Trad. Leda Tenório da Motta. Op. cit.: 53-54)

(BENJAMIN, Walter. "Sobre alguns temas de Baudelaire". Charles Baudelaire, um lírico no auge do capitalismo. Obras Escolhidas III. São Paulo: Brasiliense, 1991.)

\section{-(: 136.)}

- (GAGNEBIN, J.M. "Do conceito de mímesis no pensamento de Adorno e Benja$\min ^{\prime}$ e "Baudelaire, Benjamin e o moderno". Sete aulas sobre linguagem, memória e história. Rio de Janeiro: Imago, 1997.)

$\cdot(: 152-153$.

$\cdot(: 147$.

- (Auerbach, E. "As Flores do mal e o sublime". Trad. José Marcos Macedo e Samuel Titan Jr. Inimigo Rumor, $n$. 8. Rio de Janeiro: 7 Letras, 2000: 84.)

- (BAUDELAIRE, C. O Spleen de Paris: pequenos poemas em prosa. Trad. Leda Tenório da Motta. Op. cit.: 83) horizontal, que corre. Assim fazendo, rompe com a duração característica da vida social. O filósofo procura no poema em prosa "O relógio", de Baudelaire, o motivo dos olhos do gato, em que o poeta vê as horas, "sempre a mesma hora, uma hora vasta, solene, grande como o espaço, sem repartição de minutos nem de segundos - uma hora imóvel que os relógios não marcam”... "Sim, vejo a hora, agora é a Eternidade!"*

Já na leitura de inspiração marxista de Benjamin, ${ }^{*}$ uma tensão permanente atravessa a obra do poeta em relação ao tempo, seja o novo, que o atrai e deprime, seja o da memória: "No spleen o tempo está reificado". " Segundo explicita Jeanne-Marie Gagnebin, "em sua leitura da poesia de Baudelaire a partir dos estudos de Benjamin, dela depreende-se a transformação da cidade e das pessoas em valor de troca, espaço para a circulação da mercadoria, aguçando o sentimento de transitoriedade. O tempo moderno "indica a alienação do trabalho no capitalismo, submetido ao tempo abstrato, inumano e insaciável dos relógios". Como na fotografia e no jornal, os fatos reproduzidos tendem tão-somente à informação, desprovidos de aura. Ao contrário, observa ainda Jeanne-Marie, o trabalho de escrita do poema "opõe-se à destruição", "descreve o trabalho do tempo e da morte, mas ao dizê-lo, luta contra ele". Por isso, ao elogiar a arte de Constantin Guys, Baudelaire ressaltaria como qualidade principal o fato de ele não pintar "segundo a natureza, mas segundo a memória, que permitir-lhe-á captar a síntese, a totalidade, a essência, em vez de ficar preso ao aleatório. É sempre a mesma luta contra o tempo que não pode ser detido na realidade concreta". Desta forma, a resistência contra a vida administrada é a matriz da idéia da representação artística como rememoração e arabesco.

Na utopia de bem-aventurança do "Quarto duplo", superou-se por um instante o esforço continuado do trabalho, o vergar-se contínuo e opressivo à matéria e ao fazer mecânico. O eu-lírico baudelairiano exige do vidraceiro que saia da atmosfera pesada que cobre a cidade como uma tampa de tédio e dê a ver as cores do Paraíso. As imagens de "minha triste miséria" indicam um "horizonte bloqueado, a prisão úmida e pútrida do inferno", reflete Auerbach," que só podem ser revogadas pelas tentativas de assalto e pelas palavras de blasfêmia, como quando a raça de Caim sobe aos céus e destrona Deus: "os sinos saltam de súbito com fúria/e lançam aos céus um urro terrível”* - pois não será tangendo plácidos que eles 
romperão a seqüência monótona do cotidiano aprisionador e alcançarão os ouvidos da divindade. Tanto na série dos poemas do Spleen, quanto em "O mau vidraceiro", divisamos o mesmo tom entre a súplica e a revolta (por vezes mescladas ao gesto violento) ${ }^{11}$ que reencontramos em "O cisne", quando este olha para o céu vazio implorando por água. Conforme percebeu Oehler, "o desejo mudo do pássaro branco é idêntico afinal ao desejo em voz alta do poeta-narrador, a quem o demônio deu asas: ambos clamam pelo trovão libertador, que purificará o mundo presente e o transformará num mundo belo, onde vale a pena viver."*

Mas, é necessário ainda ressaltar que Baudelaire nunca se exime de enfrentar o real em toda sua gama de aspectos desagradáveis e grotescos. Buscar o imaginário não é edulcorar ou ignorar a miséria da vida urbana. Tanto n'“O mau vidraceiro" quanto n'“ $\mathrm{O}$ quarto duplo”, visões de mundo distintas nos são igualmente apresentadas - em contraste.

Pois, sob a égide da figura do vidraceiro, deparamo-nos com duas atitudes bem diversas frente à mimese: seja a que acredita denunciar um aspecto do real, aderindo ao tempo e espaço presentes, e submetendo a vida a uma suposta descrição, repetidora; seja a que se recusa à mera cópia, detendo-se nela e ultrapassando-a. Estabelece-se com o real uma relação de contestação e mesmo transformação, tendo sua origem numa "tristeza que só pode provir de um entusiasmo despertado pelo Ideal" ${ }^{12}$ - consciente da fricção entre spleen no presente e ideal na imaginação. Os Petits poèmes en prose de Baudelaire pretendem abreviar o caminho entre um e outro, enxertando, na prosa da existência, um broto potente, ou "imp"13, de pequenos poemas.

\footnotetext{
${ }^{11} \mathrm{Na}$ expressão de Benjamin, o verso de Baudelaire é "insondavelmente inconsolável", uma vez que foi perdida a possibilidade da experiência: "não é senão essa incapacidade que constitui a essência da ira." (Op. cit.: 135)

${ }^{12}$ De acordo com os termos de Schiller definindo a elegia no mundo moderno, cujo sentimento dominante é reconhecer que a natureza foi perdida e o ideal é inatingível, em Poesia ingênua e sentimental. São Paulo: Iluminuras, 1991: 69-71. Também Benjamin conclui do primeiro ciclo de poemas d'As flores do mal que "bem poderia estar dedicado a algo irremediavelmente perdido" (Op. cit.: 132). ${ }^{13}$ A palavra "imp", traduzida por "demônio", alude à idéia de espírito incubo, encosto, e significa, na sua origem etimológica, broto ou enxerto.
}

*(OEHLER, D. O velho mundo desce aos infernos: auto-análise da modernidade após o trauma de 1848 em Paris. Op. cit.: 298.) 


\section{Viviana Bosi}

Viviana Bosi é professora de Teoria Literária na Universidade de São Paulo. Escreveu o livro John Ashbery, um módulo para o vento (1998). Organizou, com três colegas, os livros $O$ poema: leitores e leituras e Fiç̧ôes: leitores e leituras. Publicou diversos ensaios sobre poetas brasileiros contemporâneos (Ana Cristina Cesar, Francisco Alvim, Armando Freitas Filho, Rubens Rodrigues Torres Filho e outros).

Palavras-chave: Baudelaire;

"O mau vidraceiro"; poética; mimese.

\section{Resumo}

A obra teórica e poética de Baudelaire se debruça diversas vezes sobre a questão da representação, ora criticando o realismo "pedreiro", ora caricaturizando o romantismo mais edulcorado. No Spleen de Paris: pequenos poemas em prosa, tal discussão assume uma configuração até mesmo ética, quando, n' "O mau vidraceiro", o poeta se insurge contra o próprio mecanismo da reprodução, seja do ponto de vista artístico, seja do ponto de vista social. Ao comparar esse texto com o de seu amigo e editor Arsène Houssaye, que publicara o poema em prosa "A canção do vidraceiro" sobre tema similar, percebe-se que duas concepçôes de mimese são oferecidas, cada qual revelando uma poética e uma visão de mundo bem distintas. 


\begin{abstract}
Baudelaire's theoretical and poetic work deals repeatedly with the question of representation, either critizing the "brickmason's" realism, or a certain kind of sugary romanticism. In Paris Spleen: Little Prose Poems, this discussion assumes an ethical configuration, when, in "The Bad Glazier", the poet rebels against the mechanism of reproduction itself, both from the artistical point of view and from the social point of view. Comparing this text with the one written by his friend and publisher Arsène Houssaye, who had published his poem in prose "The glazier's song" about a similar theme, we may notice that two conceptions of mimesis are conveyed, each one revealing a very different perspective on poetics and life.
\end{abstract}

\section{Résumé}

L'oeuvre théorique et poétique de Baudelaire aborde à plusieurs reprises la question de la représentation, tantôt pour critiquer le réalisme "maçon" tantôt pour caricaturiser le romantisme le plus édulcoré. Dans Le spleen de Paris: petits poèmes en prose, cette discussion revêt même un aspect éthique, au moment où, dans "Le mauvais vitrier", le poète s'insurge contre le mécanisme même de la reproduction, soit du point de vue artistique, soit du point de vue social. En comparant ce texte avec celui de son ami et éditeur Arsène Houssaye, qui avait publié le poème en prose "La chanson du vitrier" portant sur un thème similaire, on s'aperçoit qu'on a affaire à deux conceptions de mimesis, chacune révélant une poétique et une vision du monde bien distinctes.
Key words: Baudelaire; "The Bad Glazier"; poetics, mimesis.

Mots-clés: Baudelaire; "Le mauvais vitrier"; poétique; mimesis. 